\title{
Discrete Sturm-Liouville equations with point interaction
}

Güher Özbey ${ }^{1}$, yelda $\mathrm{AYGAR}^{2}$, and Basak Oznur ${ }^{3}$

${ }^{1}$ Ankara Üniversitesi Fen Bilimleri Enstitüsü

${ }^{2}$ Ankara University

${ }^{3}$ Gazi University

January 4, 2022

\begin{abstract}
Scattering solutions and several properties of scattering function of a discrete Sturm-Liouville boundary value problem with point interaction (PBVP) are derived. Moreover, resolvent operator, continuous and discrete spectrum of this PBVP are investigated. An asymptotic equation is utilized to get the properties of eigenvalues. An example illustrating the main results is given.
\end{abstract}

\section{Hosted file}

Discrete Sturm-Liouville equations with point interaction.pdf available at https: //authorea.com/users/453913/articles/551683-discrete-sturm-liouville-equations-withpoint-interaction

\section{Hosted file}

Discrete Sturm-Liouville equations with point interaction.tex available at https: //authorea.com/users/453913/articles/551683-discrete-sturm-liouville-equations-withpoint-interaction 